Educational Research for Social Change (ERSC)

Volume 10 No. 2 September 2021

pp. 161-177

ersc.nmmu.ac.za

ISSN: 2221-4070

\title{
An Exploration of Pre-Service Student Teachers' Understanding of Social Justice Issues Through Theatre-in-Education ${ }^{1}$
}

\author{
Logamurthie Athiemoolam \\ ORCID No: 0000-0002-7844-1434 \\ Nelson Mandela University \\ Logamurthie.athiemoolam@mandela.ac.za
}

\begin{abstract}
The aim of this qualitative study was to establish how students' understanding of social justice was enhanced through their participation in the theatre-in-education process, and its contribution to their learning. The population of the study comprised all students registered for the third-year education module, Issues and Challenges in Education-PGED 302. The population included Bachelor of Education (Foundation Phase, Intermediate Phase, and FET) students. Of the population of 300 students registered for the module, only 72 Bachelor of Education (Intermediate Phase) students who participated in the theatre-in-education presentations, constituted the sample for the study. Data comprised students' written reflections based on their theatre-in-education experiences, which were coded and analysed thematically. The study indicated that students' understanding of social justice in education was enhanced through their participation in their theatre-in-education presentations.
\end{abstract}

Keywords: theatre-in-education, social justice education, pre-service teacher education, critical performative pedagogy, drama pedagogy

Copyright: @ 2021 Athiemoolam

This is an open access article distributed under the terms of the Creative Commons Attribution NonCommercial License, which permits unrestricted non-commercial use, distribution, and reproduction in any medium, provided the original author and source are credited.

Please reference as: Athiemoolam, L. (2021). An Exploration of Pre-Service Student Teachers' Understanding of Social Justice Issues Through Theatre-in-Education. Educational Research for Social Change, 10 (2), 161-177. http://dx.doi.org/10.17159/2221-4070/2021/v10i2a10

\section{Introduction}

If teacher educators are to prepare pre-service teachers adequately to teach in diverse learning contexts, it is imperative that they make their students aware of the importance of promoting social justice in teaching and learning environments. For this to be realised, however, teacher educators need to implement strategies in their classes that will create the conditions in which pre-service teachers become aware of and develop their own voice, power, and agency. The adoption of such a process will enable students to challenge multiple social injustices that privilege some groups on the basis of

\footnotetext{
${ }^{1}$ Ethical clearance number: H17-EDU-ITE-019
} 
language, religion, class, gender, race, ethnicity, sexual orientation, and disability-amongst other social signifiers - at the expense of others (Kumashiro, 2000).

Although schools contend that they are making concerted efforts to address issues of oppression, they often, as highlighted by Kumashiro (2009, p. xxxvi), reinforce it "or at least allow it to continue playing out unchallenged and often without realising that they are doing so." Hence, it is imperative that teacher educators embrace appropriate pedagogies in their classes that will serve to create opportunities for their students to think critically about social injustice in school contexts, and to make their voices heard. This could be achieved through, amongst others, embodied learning, which entails that students use both their bodies and their minds to convey meaning. Having used embodied learning in the form of drama and theatre-in-education in my classes over a number of years in my role as a teacher educator, I can attest to its significance in enhancing students' critical and creative thinking skills. Hence, I resolved to use theatre-in-education as a strategy to stimulate pre-service teachers to reflect more broadly on their experience of social justice issues in the context of their own teaching practice experiences through sharing their personal stories, which lead to the creation of group plays.

It was envisaged that, through the implementation of drama pedagogy and motivating my students to create their own plays based on social justice, they would reflect more closely on both social justice issues and on the ways in which we are socialised into certain patterns of behaviour through habitus. According to Österlind (2008), theatre has the potential to physically represent the power dynamics manifest in society thereby making habitus visible. In this way, as pointed out by Werner (2017, p. 16), "these manifestations of social forces can help students recognise the power structures that lead to oppression; a necessary step on the path to achieving social justice." In so doing, students will be better predisposed to identifying how power and privilege are manifested in school contexts.

Hence, this study aimed to explore how pre-service Intermediate Phase teachers' understanding of social justice issues was enhanced through their participation in theatre-in-education productions. Further details relating to the conceptualisation of theatre-in-education and its application are provided in the literature review section.

\section{Theoretical Framework}

\section{Critical Pedagogy and Critical Performative Pedagogy}

The study was informed by critical pedagogy and critical performative pedagogy because these are closely aligned to an interrogation of social justice issues in society at large. According to Elliot (2007, p. 1) critical pedagogy conceives the school "as a problematic space of racial, economic, moral and social tension requiring deep interjection of social justice and civic courage." Consequently, teachers have a crucial role to play in conscientising their learners to the ways in which social injustice manifests in society by perceiving them as co-constructors of knowledge and by relinquishing their roles as custodians of knowledge (Freire, 1970). This is how I perceive my role as a lecturer teaching the thirdyear Education module (Issues and Challenges-PGED 302) to my Bachelor of Education (BEd) Intermediate Phase (Grades 4-6) pre-service teachers.

Given that schools are characterised as sites of struggle, "critical pedagogy approaches the classroom as an opportunity for doing political and social work with and for students, teachers and the communities in which they live" (Giroux 1993, p. xxiv). In the context of this study, critical pedagogy entailed my willingness to recognise my students as co-constructors of knowledge so that they could gain enhanced understandings of social justice in the schooling context, based on their lived experiences. 
The performative component of critical pedagogy is realised when critical reflection is embodied, and when teachers create opportunities for learners to experience theory in action by recreating lived experiences through dramatic performance (Giroux, 2011; McLaren, 1989; Pineau, 1994). The aim of critical performative pedagogy is thus to integrate students' critical reflection with their potential for social engagement and transformation through embodied learning (Botha, 2009; Dalrymple, 1997). Through embracing critical performative pedagogy as a theoretical framework, the pre-service student teachers were perceived as co-constructors of knowledge, while I perceived my role as a facilitator of learning. This contributed to enhanced learning, since the students were afforded opportunities to create their own plays and to critically reflect on their experiences based on the process.

\section{Literature Review}

\section{Social Justice Education}

According to Bell $(1997$, p. 3), "social justice is both a process and a goal that involves full and equal participation of all groups in a society that is mutually shaped to meet their needs." The focus of this collaborative process is thus on democracy and freedom to exercise one's full humanity (Belle, 2019) so that one is afforded equal opportunities to achieve one's goals and ambitions in society. In the context of the educational environment, this implies that all learners need to be supported to achieve academic success through the development of critical and creative skills. Social justice education thus encourages all learners to play an active role in their own education and supports teachers in the creation of "empowering, democratic and critical education environments" (Hackman, 2005, p. 103) for their learners. Teachers thus need to recognise that their learners have valuable contributions to make to the classroom space, as opposed to what Belle (2019, para. 1) referred to as "social, cultural and academic burdens on the so-called master in the room-the teacher." Furthermore, because education is a political act, we cannot talk about schools without addressing issues of race, class, gender, ability, sexuality, and politics (Belle, 2019). Hence, in preparing pre-service teachers to understand the crux of social justice education in their future roles as teachers, it is imperative that teacher educators guide their students to an awareness of reform traditions, particularly social justice philosophies, and implement pedagogies that will enhance their understanding of social justice during their teaching (McDonald \& Zeichner, 2009). In my role as a socially just teacher educator, I aim to conscientise my students to the ways in which the school contexts and practices militate against learners from disadvantaged communities. The process, as highlighted by Dover $(2013$, p. 5), involves challenging the political neutrality of the classroom and curriculum, pedagogy, and education system and seeking to "develop students' socio-political consciousness through co-investigation, problemposing and dialogue." Through this process, as pointed out by Belle (2019, para. 5), pre-service teachers come to terms with the ways in which their education has been oppressive, "while thinking through solutions for not repeating this cycle, once they step into the classroom." In the context of this study, the theatre-in-education presentations focused on identifying various manifestations of social injustice in specific school and classroom contexts and providing solutions to the issues highlighted in the plays.

\section{Drama Pedagogy and Theatre-in-Education for Social Change}

According to Siegesmund (1998), the aim of drama pedagogy for critical pedagogues is to focus on the development of critical consciousness through social transformation. In this sense, as pointed out by Davies (2014), it has the potential to challenge social injustice thereby contributing to social change. This is further supported by Dalrymple (1987) who, as the first South African to recognise the value of theatre-in-education as an "applied problem-solving arts practice" (Durden \& Tomaselli, 2012), used it as a strategy to effect behaviour change among young people. By focusing on the liberatory nature of education through the adoption of Boalian theatre-in-education practices for behaviour change with a focus on HIV and Aids, Dalrymple (1992) explored how theatre-in-education could lead to behaviour 
change. In her arguments, she opined that the holistic nature of drama pedagogy, which is also participatory and experiential, "provides a broad framework in which to explore ideas from a range of different perspectives" (Dalrymple, 1997, p. 84).

This is further supported by Greene (1991, p. 166) who argued that the arts and aesthetic experiences "provide ground for the questioning that launches sense making and the understanding of what is to exist in the world." Drama pedagogy, which is closely aligned to critical pedagogy, and which applies the ideas of Freire (1970), aims to impact participants' lives in positive ways for their own personal transformation (Neelands, 2007). Such an approach is closely linked to "identity recognition and personal transformation (empowerment) as a means to social change" (Giambrone, 2016, p. 18). According to Boal's (1979) theory, in this sense, individuals can influence reality through their dramatic performance in which they might highlight how social transformation could be achieved to impact the lives of those on the periphery of society.

Theatre-in-education, which is one of the strategies of drama pedagogy, is an approach that uses interactive theatre and drama practices to help aid the education process. Its main goal is to offer creative learning opportunities through theatrical experiences (Lu, 2002). According to Tarlington \& Michaels (1995), the theatre-in-education process commences with the sharing of ideas on a social issue that constitutes the theme for the creation of a play to an audience. The teacher facilitates the play building process through various drama-in-education techniques such as tableau and improvisation. However, the students select the theme for the play, write the script, and develop, produce, direct, and present the play on their own to an audience. This collaborative process, according to Tarlington \& Michaels (1995), involves the entire group being engaged in the process of improvisation for the creation of the performance text.

After presentation of the play to the audience, the participants and audience reflect on the issues that the play engages with and provide their insights based on their experiences. According to Jackson $(2001$, p. 1), the aim of theatre-in-education is to "actively engage the audience in the learning process." In this study, pre-service teachers wrote, directed, produced, and presented their own plays based on social justice issues to the lecturer and their peers in a university classroom setting. Generally, as pointed out by Lu (2002), the play presents an identifiable situation about the leading character (protagonist) whose crisis needs to be resolved. Because the play evokes the students' thoughts about the theme behind the protagonist's dilemma, the students can recognise the issues involved, reflect on them, and critically interrogate them.

\section{Research Methodology}

An arts-based qualitative research methodological approach referred to as performative inquiry, and that shares characteristics of ethno-drama (Fels, 2004), was used for the purposes of this research study. According to Fels (1998), performative inquiry is a research methodology that uses drama to understand critical issues affecting society. The implementation of this qualitative approach involves the participants' engagement with a theme of concern and the use of performative inquiry to showcase their issue of concern (Fels, 2004). In this study, the pre-service teachers were involved in performative inquiry by conceptualising and presenting a play on a social justice issue of concern, based on their school-based learning experiences (Tarlington \& Michaels, 1995).

The characteristics of arts-based research is that it, as described by Finley $(2005$, p. 686), "provides a formula for a radical, ethical and revolutionary qualitative inquiry." In this case, the play was used for the purposes of "self-reflection, self-expression and communication" (Finley 2005, p. 686) among the participants in the production. 
The study's design was phenomenological in nature in that it aimed to construct detailed descriptions of social reality through using natural language to understand the world (de Vos et al., 2011). The population of the study represented a group of third-year education students registered for the PGED 302 (Issues and Challenges in Education) module at Nelson Mandela University. The students registered for this third-year education module included BEd students registered for the BEd Foundation Phase (Grades 1-3), BEd Intermediate Phase (Maths and Science, Grades 4-6), BEd Intermediate Phase (Language, Grades 4-6), and BEd FET (Grades 10-12). Of the population of 300 students registered for the module, the sample only included the BEd Intermediate Phase (Language) group, comprising 72 students. This sample represented students in the third-year education module from diverse linguistic, ethnic, cultural, and religious backgrounds. The students from this group participated in the plays and agreed to write reflections based on their understanding of social justice derived from their theatre-in-education experiences.

Data were collected from students' written reflections on their understanding of social justice based on the plays that they produced, presented, and participated in. The prompt that guided the students' written reflections was: "Write a reflection on the insights that you gained on social justice through your participation in, and viewing of, the theatre-in-education presentations." The written reflections were coded by using numbers, $\# \mathrm{~S}$ (student)1-72 to refer to each of the narratives representing students' insights and experiences and analysed thematically. Before the commencement of the study, permission was sought from the university's ethics committee and was granted by the provision of ethics number H17-EDU-ITE-019. Thereafter, informed consent was sought from the students and they were informed that they could withdraw from the study at any time if they wished to do so. They were also informed that the written reflections would not be used for assessment purposes.

Furthermore, the students were informed that all written reflections would be confidential and that their anonymity would be safeguarded given that they were not required to write their names on the written reflections.

The limitations of the study were that this was a small- scale study that only focused on one group of third-year education students in the PGED 302 cohort, namely, the BEd (Language) students. Consequently, the findings of the study cannot be generalised to the other PGED 302 groups registered for the module and who also covered the theme on social justice (PGED 302, Unit 3).

\section{Overview of the Module and the Theatre-in-Education Process}

The PGED 302 (Issues and Challenges in Education) module is a compulsory third-year education module of 15 credits spread over two semesters that all BEd students have to register for. The module consists of 10 themes covered over a period of two semesters ( 28 weeks) with a time allocation of one double period ( 70 minutes) per week. The following themes are covered in this module:

- Unit 1: Theory and practice in shaping democratic schooling

- Unit 2: Paulo Freire and the humanising pedagogy

- Unit 3: Social justice in education

- Unit 4: Emancipation and empowerment in the context of schooling

- Unit 5: Social constructivism

- Unit 6: Teaching diverse learners

- Unit 7: Discipline in the diverse classroom

- Unit 8: Teaching in linguistically diverse classrooms

- Unit 9: Curriculum development to cater for diverse learners

- Unit 10: Collaborative action and schooling 
This article will only focus on Unit 3 (Social Justice in Education) to uncover the students' insights into social justice education based on their theatre-in-education experiences.

\section{The Drama and Theatre-in-Education Process}

During my reflection on how to present Unit 3 (Social Justice in Education) to my students, I surmised that the implementation of drama pedagogy could represent an effective approach to enable students to present their insights on social justice in the context of their school-based learning experiences. The theme was covered over three double periods. In the first session, I initiated a discussion on the students' experiences of social justice in school contexts and discussed various theorists such as Freire (1970), Giroux (2011), and Bourdieu (1990), amongst others, and their contributions to social justice education. During this session, I also introduced them to tableau, which makes use of frozen scenes by using body sculpting to convey a message in a nonverbal manner. According to Valverde $(2003, p .1)$ the aim of the process is to capture an event, frozen in time, "as a way to achieve a deep understanding of the elements involved." The students were asked to divide themselves into nine groups and to identify a social justice issue in education that best captured their experiences of the issue while on teaching practice, and to present their frozen scenes to the class. During each of the presentations, those observing posed questions to the characters in the scenes. The class reflected on the issues raised through the tableau-building process with reference to their school-based learning experiences and by providing their own insights.

In the second session, I facilitated a workshop in which the students divided themselves into groups of eight, and were required to relate their stories on social justice issues based on their learning experiences to the members of their group. The group selected the issue from the stories narrated that best captured their experiences of social justice in their school-based learning experiences, and used this as the material for the creation of their theatre-in-education presentations. The students were thus afforded an opportunity to produce their own content on social justice for the theme covered during the series of sessions.

The plays were presented during the third session. The nine plays presented focused on the following themes and contexts as presented in Table 1. 
Table 1

The nine plays

\begin{tabular}{|c|c|c|c|}
\hline Play & Social justice issue & Context of the play & Resolution of the play \\
\hline 1 & Language inequality & $\begin{array}{l}\text { The teacher teaches maths in } \\
\text { English to a group of learners } \\
\text { whose home language is isiXhosa. } \\
\text { When the learners tell her that } \\
\text { they don't understand, she calls } \\
\text { them idiots. }\end{array}$ & $\begin{array}{l}\text { The teacher realises that she has to } \\
\text { make provision for including home } \\
\text { language in her teaching and does so } \\
\text { through peer help. }\end{array}$ \\
\hline 2 & $\begin{array}{l}\text { Inequality based on } \\
\text { socioeconomic factors }\end{array}$ & $\begin{array}{l}\text { A learner from a poor background, } \\
\text { and who is academically gifted, is } \\
\text { marginalised by a teacher because } \\
\text { of her socioeconomic status and a } \\
\text { wealthier learner is favoured at the } \\
\text { awards ceremony. }\end{array}$ & $\begin{array}{l}\text { After realising what has happened, } \\
\text { the principal steps in and gives the } \\
\text { learner recognition in the assembly } \\
\text { after the awards ceremony. }\end{array}$ \\
\hline 3 & Gender inequality & $\begin{array}{l}\text { The teacher reinforces gender } \\
\text { stereotypes by asking a boy to } \\
\text { carry a box while a girl has to } \\
\text { sweep the floor. }\end{array}$ & $\begin{array}{l}\text { One of the learners in the class } \\
\text { questions her as to why genders are } \\
\text { stereotyped in this way. On } \\
\text { reflection, the teacher realises that } \\
\text { she needs to promote gender } \\
\text { equality. Later, we see role reversal } \\
\text { in the class. }\end{array}$ \\
\hline 4 & $\begin{array}{l}\text { Inequality based on } \\
\text { socioeconomic factors }\end{array}$ & $\begin{array}{l}\text { A girl whose mom is a single parent } \\
\text { and a sex worker is exposed to sex } \\
\text { at a young age, becomes one } \\
\text { herself, and drops out of school } \\
\text { and the vicious cycle continues. }\end{array}$ & $\begin{array}{l}\text { A social worker helps her to rise } \\
\text { above her circumstances, places her } \\
\text { in a centre for abused girls where } \\
\text { she discovers her talent as a fashion } \\
\text { designer. }\end{array}$ \\
\hline 5 & $\begin{array}{l}\text { Inequality based on } \\
\text { socioeconomic factors }\end{array}$ & $\begin{array}{l}\text { A learner from a poor background, } \\
\text { who is physically and emotionally } \\
\text { abused at home and school, is } \\
\text { rebellious and aggressive. }\end{array}$ & $\begin{array}{l}\text { A friend at school helps him to come } \\
\text { to terms with his situation and to rise } \\
\text { above his circumstances by being } \\
\text { intrinsically motivated to achieve } \\
\text { success. He becomes a teacher and } \\
\text { motivational speaker and inspires } \\
\text { others. }\end{array}$ \\
\hline 6 & $\begin{array}{l}\text { Inequality based on } \\
\text { socioeconomic issues }\end{array}$ & $\begin{array}{l}\text { Parents on the school governing } \\
\text { body select wealthier learners as } \\
\text { prefects. When a learner from a } \\
\text { poor background is nominated, } \\
\text { they reject the learner-claiming } \\
\text { that learners may be equal in value } \\
\text { but different in function. }\end{array}$ & $\begin{array}{l}\text { Teachers on the school governing } \\
\text { body highlight the learner's } \\
\text { academic and leadership qualities } \\
\text { and, in this way, she is selected as a } \\
\text { prefect. }\end{array}$ \\
\hline 7 & Disability & $\begin{array}{l}\text { A learner who loses her leg in an } \\
\text { accident struggles to attend school } \\
\text { and is ridiculed, but she remains } \\
\text { resilient and positive }\end{array}$ & $\begin{array}{l}\text { The community rallies to support her } \\
\text { and raises enough money for her to } \\
\text { get a prosthetic leg. }\end{array}$ \\
\hline 8 & $\begin{array}{l}\text { Socioeconomic } \\
\text { challenges }\end{array}$ & $\begin{array}{l}\text { A learner attends school without } \\
\text { stationery and is ridiculed by } \\
\text { classmates and teachers who have } \\
\text { no sympathy for him. }\end{array}$ & $\begin{array}{l}\text { One of the teachers in the school, on } \\
\text { hearing about the learner's plight, } \\
\text { hands him a shoebox with stationary. }\end{array}$ \\
\hline 9 & $\begin{array}{l}\text { Discrimination based } \\
\text { on academic ability } \\
\text { and reading challenges }\end{array}$ & $\begin{array}{l}\text { A reader struggles to read and the } \\
\text { teacher ridicules him in front of the } \\
\text { class, describing him as a dunce. }\end{array}$ & $\begin{array}{l}\text { One of the better readers in the class } \\
\text { assists the learner after school to } \\
\text { improve his reading and } \\
\text { comprehension and his reading } \\
\text { ability improves. }\end{array}$ \\
\hline
\end{tabular}




\section{Findings}

The analysis of pre-service teachers' written reflections based on their theatre-in-education experiences on social justice issues led to the identification of the following themes: awareness of social justice issues and manifestations, identifying with themes of the plays, gaining new insights on social justice issues, awareness of the teacher's role in embracing social justice issues, and personal engagement with social justice issues. The themes illustrate that the students' viewing of the theatrein-education presentations and their participation in the plays enhanced their understanding of social justice issues on multiple levels (Desai, 1991). The findings emerging from the study are discussed thematically and verbatim excerpts from students' written reflections are used to elucidate themes.

\section{Awareness of Social Justice Issues}

In their written reflections on their understanding of social justice by participating in the plays and viewing them, some participants indicated that their understanding of social justice issues was enhanced. Their reflections indicated that they were more aware of how discrimination manifests in society and the various ways in which learners in schools could be marginalised. One of the students summed up this view as follows:

After I watched all the plays, I started to gain more knowledge on social justice issues such as gender inequality, sexual abuse, racism, sexism, and socioeconomic issues. (\#S10)

In reflecting on his own experiences of the plays, \#S2O indicated that his understanding of social justice was enhanced on so many levels and the insights that he gained from the plays enabled him to conclude:

Social justice is many things; it is anti-favouritism, anti-judgemental, anti-discrimination, uplifting, empowering, encouraging, and a whole lot more. It is about being fair and treated with the same respect; but also saying that some may need more attention than others and that we as teachers must balance those scales.

The insights he gained enabled him to reflect on social justice from a variety of perspectives, thereby enhancing his understanding of social justice. In reflecting on his understanding of social justice, \#S22 had the following to say:

I found the plays very good and inspiring and I now know what social justice is and how to strive for a better social justice future.

Another student, in reflecting on the value of the plays, indicated that the plays aimed to demonstrate the importance of embracing diversity, equity, and fairness in the class so that all learners could achieve success. This was articulated by the student as follows:

The plays set a framework aimed at resisting unfairness and inequality while enhancing freedom and the possibility for every student. (\#S28)

The advantage of theatre-in-education presentations was that both the participants and those viewing the plays elicited invaluable lessons from specific plays that enhanced their understanding of social justice. In reflecting on one of the plays that she viewed, \#S45 indicated that the play based on the learner who lost a leg in an accident (Play 7) made her realise that: 
One doesn't always think what such a person can or will go through and what effect social justice has on her. By just giving her a little support and not judging or discriminating against her, she came far.

The viewpoint expressed above indicates that the pre-service teacher has developed a greater sense of awareness of how she needs to engage with learners who may be physically handicapped in her classes. The fact that she alluded to support that such learners need to receive is indicative of her awareness that she needs to embrace social justice principles when teaching her classes.

In reflecting on the play on language barriers where learners are taught through a LOLT (language of learning and teaching) that is not their mother tongue (Play 1), one of the students described this as a major crisis in South African government schools, which he articulated as follows:

The play on language barriers in class is a true reflection of a major crisis in government schools where English is being used as a language of learning and teaching, but the majority of the learners come from homes where English is used as a second language. These learners fail dismally because little provision is made to incorporate their home language to help them grasp concepts and ideas. (\#S55)

The student's reflection on the play demonstrates that he has gained an enhanced understanding of how learners could be discriminated against if they are being taught through the medium of a language that is different from their mother tongue.

In reflecting on her experiences of social justice in the context of her school-based learning experiences and with reference to Play 8 , \#S25 felt that teachers tend to discriminate against learners based on socioeconomic backgrounds. She expressed this view as follows:

The play that stood out for me the most was the one on poverty and how teachers discriminate against learners because of their socioeconomic status. I chose this play because in SA, most of our learners don't finish their schooling because of poverty and even if they do attend school, they are discriminated against because of their socioeconomic status.

This viewpoint was further enhanced by another student as follows:

Another issue that kept arising was the issue of the "teacher's pet" and how most of the time the teachers' pets were the more privileged learners. This issue linked with the issue of privileged vs. non-privileged, and how many teachers and learners are not aware of this in their classroom and this leads them to judging the less privileged learner. (\#S36)

The student's engagement with the theme of the play on how learners are sometimes discriminated against based on socioeconomic factors (Play 2) has conscientised him to the plight of learners from poverty-stricken backgrounds who will need to be supported and motivated if they are to succeed in the schooling system.

In reflecting on how the plays enhanced their understanding of social justice issues, students felt that a crucial lesson was to ensure that they made a concerted effort to include all their learners in their lessons so that they feel valued. This viewpoint was summed up by one student as follows:

Through the plays, I could see the inclusion of everyone. I saw some empowerment of people to participate fully. (\#S20) 
The students' viewpoints on the plays indicate that the plays enabled them to be more engaged with social justice issues and to reflect more fully on these issues within school contexts.

\section{Identifying With Themes of Plays}

A number of students felt that they could identify with the themes on social justice, as their peers produced plays that focused on their teaching practice experiences. One student summed this viewpoint up as follows:

Many of the social justice issues that we addressed was based on things that we student teachers face every day in schools, and coming to class sharing what we experience and what we do to make changes brings such a good and overwhelming feeling. (\#S70)

This viewpoint was also highlighted by one of the students as follows:

The fact that some of the plays were based on students' lived experiences made them so much more real. (\#S18)

And another student advanced the following view:

One thing I noticed about the presentation is that my fellow colleagues imitated what was really happening at their chosen schools for their practical teaching. (\#36)

Because the plays touched on social justice issues that many of the students could identify with from their school-based learning experiences, the theatre-in-education process showcased lived experiences, thereby enhancing their knowledge in the field of social justice.

\section{Multiple Perspectives of Reality}

The students' participation in and viewing of their fellow students' plays enabled them to gain new insights and perspectives on social justice and the range of issues they were likely to experience in their future roles as teachers.

This was succinctly summed up by one of the students who came from a different schooling context from most as follows:

Coming from a reasonably privileged background and having attended an ex-Model $C$, school I was quite shocked to see what some of my fellow students depicted in their social justice presentations. A lot of these things I have heard of before, but having seen dramatic illustrations of the issues made it so much more of a reality. (\#S36)

The focus on how one's insights could be enhanced on issues based on experiences of social justice through the theatre-in-education presentations was succinctly summed up by \#S68 as follows:

Our own idea of teaching can have an impact on others and working with different cultures can broaden one's knowledge and change our ideas of what is ideal and what is right.

This was further elaborated on by \#S52: 
The case studies I observed through theatre was interesting as everyone had something different and it made me think differently about things.

The students' viewpoints illustrate that the plays served to enhance their understanding of social justice issues.

\section{Awareness of Teacher's Role in Embracing Social Justice Issues}

The students' written narratives indicated that their viewing and participation in the plays enabled them to reflect more carefully on their future roles as teachers who will be required to teach in diverse learning contexts.

One of the students contended that by viewing the plays he has come to the realisation that:

It is in the classroom where we could make the biggest difference in our roles as teachers, but I will need to be aware of injustices they face and support them. (\#S63)

This is an important realisation because it demonstrates a sense of awareness that teaching has broader connotations than merely conveying knowledge, and that the learners' experiences also need to be considered. This realisation of adopting a humanising pedagogy (Freire, 1970), that considers how teachers should engage with learners, was further enhanced by one of the students as follows:

We must take into account that we do not know everyone's circumstances and so we need to be careful what we say and how we treat our learners. (\#S46)

There was a further realisation that, because these plays portrayed issues that the students have either experienced personally or are likely to experience in their future roles as teachers, they will have to adopt classroom practices that take their learners' needs into account and avoid being judgemental. One of the students expressed this viewpoint as follows:

What I take from this is that I need to be careful in my classroom not to make quick judgements regarding students and I should be aware of possible injustices they face and try to help them transcend their circumstances. (\#S33)

This was further elaborated on by \#S41:

Some teachers may have favourites while others have a child who is being abused. How we handle these situations, as teachers, could affect the children's lives.

In reflecting on specific lessons that the plays conveyed to teachers to make them more aware of challenges they will experience relating to social justice, one student indicated that they needed to be more aware of their learners' circumstances, as depicted in the play on the silent child (Play 4). The student expressed this view as follows:

We as, future teachers, will come across learners who come from abusive and violent homes and cannot concentrate. In most of these cases, these learners end up committing suicide because they have no one to talk to or help them out of their situation. (\#S59) 
Some students expressed the viewpoint that the plays enabled them to reflect on the kind of teachers that they would like to be. Student \#S55 felt that the plays made her more aware of how she saw her future role as a teacher, which she expressed as follows:

I really enjoyed watching the different plays and scenarios that were portrayed in the class. It gave me a sense of what kind of teacher I would want to be one day, which is a humanising teacher.

The plays enabled students to become more aware of their future roles as humanising teachers who should aim to develop their learners holistically and not just academically.

\section{Personal Insights Gained}

Students were able to engage with social justice issues on a personal level through viewing the plays. This enriched their insights and made them more aware of how social justice issues could be manifested within the schooling system.

One of the students, in reflecting on her group's play (Play 7), indicated that the value of the play was that it cultivated resilience among the students, which she expressed as follows:

In our group presentation, we did a play about a girl who lost her leg in a freak accident. I think we showed everyone that anything is possible if you put your mind and heart to it. No matter what the circumstances, there is always a way out. (\#S10)

Another student, in reflecting on the same play, described her personal engagement with the play as follows:

The story about the little girl who was in an accident and never gave up even though her legs were hurt really inspired me to never give up no matter how hard or tough life could be. (\#S16)

In reflecting on how the plays promoted personal engagement with the issues, one of the students indicated that the play enabled her to understand why learners exhibit anti-social behaviour. She expressed this viewpoint as follows:

The one play showed me, as a teacher, not to look down on the learner who is anti-social, awkward, and always quiet in class because learners and even we, as teachers, do not know what the situation is at home for that learner. (\#S54)

An important lesson emerging from the plays relating to teaching and learning was valuing all voices in the classroom. This viewpoint of providing multiple perspectives of reality by making all learners' voices heard was expressed as follows by one of the students:

My idea of social justice from the plays that were presented is allowing every person or learner's voice or opinion to be heard and respected. By doing that, we create room for democracy that is fair and honest where exclusion does not exist. (\#S6)

In their engagement with the issues arising from the plays on a personal level, the students' reflections indicate that the plays stimulated them to reflect on their future role as teachers. This future role 
involved embracing democratic teaching principles that embody humanising practices as espoused by Freire (1970), Giroux (2011), Bourdieu (1990), and others.

\section{Discussion}

The findings indicate that the students' active participation in the development of their own improvised plays contributed to their understanding of social justice on multiple levels. The participants indicated that they gained a better understanding of how social justice issues manifested in the schooling environment, and acquired insights into social justice-related themes and issues. The theatre-in-education process furthermore enabled them to develop multiple perspectives of reality, made them more aware of their roles as socially just teachers, and motivated them to engage personally with the social justice issues highlighted in the plays (Desai, 1991).

The embodied learning that characterises critical performative pedagogy enabled the students to "take the classroom stage, create their own roles and develop their own voices to shape their own learning and to make it their own through the process of co-construction" (Even, 2018, p. 102). In the context of this study, because the students could engage with the social justice issues on a more personal level by relating them to their teaching practice experiences, the learning was more purposeful and transformative. Indeed, the findings indicate that students developed new insights on social justice based on their viewing and involvement in the plays, which, for some of the students, was a cathartic experience (Dalrymple, 2006). Furthermore, the insights that they gained from the plays enabled them to reflect more closely on the social justice issues that they needed to take cognisance of in their future role as teachers. This demonstrated that they were able to relate their own learning on social justice issues from the plays to their role as transformative teachers who embraced social justice education (Bourdieu, 1990). The implementation of theatre-in-education involved a change in the focus "from the production of correct answers to intense exploration of content through the engagement of minds, bodies and emotions" (Even, 2018, p. 104). The process enabled the students to make learning matter to them as they recreated social justice issues in school contexts through co-constructed performance while the lecturer became a "co-traveller in [the] journey of discovery" (Even, 2018, p. 104). This led to the development of their critical reflective skills as demonstrated by their personal accounts of their engagement with social justice issues emerging from the plays (Dalrymple, 2006; Freire, 1970). The development of critical consciousness on social justice issues through the use of drama, according to Teoh (2012), is significant in that it serves as a vehicle for deeper understanding of concepts and culture through enactment, dialogue, and exploration.

The students' viewpoints indicate that they gained more enhanced insights into social justice in terms of inequality and discrimination in the classroom, and the various ways in which teachers are responsible for promoting such inequality. Hence, the emancipatory knowledge that was coconstructed through the theatre-in-education process, as highlighted by the findings of this study, enabled them to understand how relations of power and privilege distort and manipulate social relations (Aliakbari \& Faraji, 2011; Ebewo, 2017).

In their theatre-in-education presentations, the students engaged with themes such as language inequality, inequality based on socioeconomic factors, disability, and gender stereotyping that were of concern to them. According to Gallagher (2016), one of the advantages of drama pedagogy is that it could lead to a leap in the imagination between what participants previously knew and what might be newly, imaginatively, known. This was clearly articulated by student \#S36 who indicated that the plays conscientised her to social justice issues that she was unaware of, thereby making her more aware of her privileged position. Through the plays, she was able to come to terms with her own privileged position, gain new insights, and question her habitus (Bourdieu, 1990). 
There was also a realisation that social justice education "involves full and equal participation of all groups in a society that is mutually shaped to meet their needs" (Bell 1997, p. 3). This was demonstrated in their analysis of those characters in the plays who were privileged and had power, and those who were marginalised and disadvantaged. Through their interrogation of issues of power and privilege in school contexts, there was a greater sense of awareness of how societal rules have the potential to govern our behaviour. According to Werner (2017, p. 15) these rules "reproduce traditions and the status quo through physical manifestations" and because these "rules, habits and behaviours" are inculcated in us from a young age, it is difficult for us to change them. Bourdieu (1990, p. 56) referred to these patterns of socialisation as the habitus, which he defines as "embodied history, internalised as a second nature and so forgotten as history; as the active presence of the whole past of which it is the product." According to Werner (2017, p. 15), we can effect social change and interrogate the roles prescribed for us by society, by "challenging our habitus; the status quo that is unconsciously and unquestioningly manifested through our very bodies." Given that creating pieces of theatre and enacting roles in plays involves "the conscious choice of bodily movements and physical mannerisms," they provide ideal opportunities to "confront and change our habitus" (Werner 2017, p. 15). In this way, we are able to question social injustice in the school environment, come to terms with our own prejudices, and arrive at new insights in terms of societal norms and how social injustice is manifested in society.

In reflecting on their roles as future teachers through drama pedagogy, the students were conscientised to the struggles of disadvantaged learners and the discrimination that they have to contend with on a regular basis (Durden \& Nduhura, 2007). This motivated them to reflect on the importance of embracing humanising approaches to teaching so that learners become co-constructors of knowledge with the teacher and so that their voices could be heard (Freire, 1970).

The personal insights the pre-service teachers gained through the play building process led to a greater understanding of how learners are discriminated against based on socioeconomic factors and learning challenges. This enabled them to reflect more carefully on their own philosophies of teaching, and how the adoption of a humanising pedagogy could contribute to a pedagogy of hope among their learners. As Clifford et al. (1999, p. 17) reminded us, it is "through bringing our mind, body and spirit to drama, [that] we gain insight into ourselves." In doing so, personal understandings can be validated and affirmed, which can be both empowering and liberating (Boon \& Plastow, 2004; Clifford et al., 1999; Ebewo, 2017). The students' understanding of social justice issues through the play building process demonstrates that they were able to engage critically with the issues, thereby enhancing their understanding of social justice education.

\section{Conclusion}

Teacher educators have a crucial role to play in making pre-service teachers aware of how social injustice is practised in classroom and school contexts. This could be achieved through implementing pedagogies in their teacher training programmes that contribute to students' sense of agency and that provide them with skills to confront social injustice in these contexts. Pedagogies such as critical performative pedagogy and drama pedagogy provide invaluable opportunities for critical engagement with social justice issues on multiple levels-as highlighted in this study. The implementation of a theatre-in-education approach enabled pre-service teachers to be conscientised to the various manifestations of social justice issues and to engage with the issues on both personal and societal levels in their roles as future teachers.

According to Gjaerum (2013), because applied theatre is a relatively new field in theatre studies internationally, there is a need to conduct more focused research in the field. In his review of the literature in the field of applied theatre, he identified the following discourses: the legitimating, the 
effect, the ethics, the outsider-visitor, the global economy, and the aesthetic discourse (Gjaerum, 2013). This study builds on knowledge in the legitimating discourse in that it legitimates the value and power of theatre-in-education in making participants aware of how social injustice manifests in schools and classrooms.

The liberatory function of drama pedagogy enables students to provide accounts of their personal experiences of social injustice in school contexts during their teaching practice experiences, and to translate them into embodied performances through the theatre-in-education process. In this way, learning proceeds from a cognitive to a visceral level that has the potential to uncover and shape values and provide rich learning experiences.

\section{References}

Aliakbari, M., \& Faraji, E. (2011). Basic principles of critical pedagogy. 2nd International Conference on Humanities, Historical and Social Sciences (IPEDR) vol.17. IACSIT Press. http://www.ipedr.com/vol17/14-CHHSS\%202011-H00057.pdf

Bell, L. A. (1997). Theoretical foundations for social justice education. In M. Adams, L. A. Bell, \& P. Griffin (Eds.), Teaching for diversity and social justice: A sourcebook (pp. 3-15). Routledge.

Belle, C. (2019, January 23). What is social justice education anyway? Education Week. https://www.edweek.org/ew/articles/2019/01/23/what-is-social-justice-education-anyway.html

Boal, A. (1979). Theatre of the oppressed. Pluto.

Boon, R. M., \& Plastow, J. (2004). Theatre and empowerment: Community drama on the world stage. Cambridge University Press.

Botha, P. (2009). The application of Paulo Freire's pedagogy in renegotiating HIV-stigmatised identities: A study of DramAidE's health promotion project (HPP) at the Durban University of Technology [Unpublished master's dissertation]. University of KwaZulu-Natal.

Bourdieu, P. (1990). The logic of practice. Stanford University Press.

Clifford, S., Hermann, A., \& Davidson, A. (1999). Making a leap: Theatre of empowerment. Jessica Kingsley.

Dalrymple, L. (1987). Some thoughts on drama, theatre and the curriculum. South African Theatre Journal, 1(1), 85-139. http://www.jstor.org/stable/41342475

Dalrymple, L. (1992). A drama approach to AIDS education: An experiment in action research. AIDS Bulletin: Medical Research Council, 1, 22-23.

Dalrymple, L. (1997). The use of traditional forms in community education. Africa Media Review, 77(1), 75-91.

Dalrymple, L. (2006). Has it made a difference? Understanding and measuring the impact of applied theatre with young people in the South African context. Research in Drama Education: The Journal of Applied Theatre and Performance, 77(2), 201-218. https://doi.org/10.1080/13569780600671070

Davies, L. (2014). Interrupting extremism by creating educative turbulence. Curriculum Inquiry, 44(4), 450-468. https://doi.org/10.1111/curi.12061

Desai, G. (1991). Theatre for development in Africa. Research in African Literatures, 22(3), 6-9.

Dover, A. G. (2013). Teaching for social justice: From conceptual frameworks to classroom practices. Multicultural Perspectives, 15(1), 3-11. https://doi.org/10.1080/15210960.2013.754285

de Vos, A., Strydom, H., Fouche, C., \& Delport, R. (2011). Research at grassroots. van Schaik. 
Durden, E., \& Nduhura, D. (2007). The use of participatory forum theatre for HIV/AIDS education in the workplace. Communicare, 26(2), 56-70. https://www.jstor.org/stable/41342475

Durden, E., \& Tomaselli, K. (2012). Theory meets theatre practice: Making a difference to public health programmes in Southern Africa. Professor Lynn Dalrymple: South African scholar, activist, educator. Curriculum Inquiry, 42(1), 80-102. https://doi.org/10.1111/j.1467-873X.2011.00575.x

Ebewo, P. J. (2017). Applied theatre as an alternative communication approach for the development of rural communities in Africa. Communitas, 22(6), 75-86. https://doi.org/10.18820/24150525/Comm.v22.6

Elliot, D. (2007). Puerto Rico: A site of critical performative pedagogy. Action, Criticism and Theory for Music Education, 6(1), 1-24. http://act.maydaygroup.org/articles/Elliott6_1.pdf

Even, S. (2018). Nothing moves if you don't let go: Performativity in teacher training. In O. Mentz \& M. Fleiner (Eds.), The arts in language teaching: International perspectives: Performative- aesthetic (pp. 91-106). LIT.

Fels, L. (1998). In the wind, clothes dance on a line. Journal of Curriculum Theorising, 14(1), 27-36. https://www.researchgate.net/profile/Lynn-

Fels/publication/292730889 In the wind clothes dance on a line/links/5807eb9f08ae63c48fe c79d2/In-the-wind-clothes-dance-on-a-line.pdf

Fels, L. (2004). Complexity, teacher education, and the restless jury: Pedagogical moments of performance. Complicity: An International Journal of Complexity and Education, 1(1), 74-98. https://doi.org/10.29173/CMPLCT8716

Finley, S. (2005). Arts-based inquiry: Performing revolutionary pedagogy. In N. Denzin \& Y. Lincoln, Y. (Eds.), The SAGE handbook of qualitative research (p. 681-694). SAGE.

Freire, P. (1970). Pedagogy of the oppressed. Continuum.

Gallagher, K. (2016). Responsible art and unequal societies: Towards a theory of drama and the justice agenda. In K. Freebody \& M. Finneran (Eds.), Drama and social justice: Theory, research and practice in international contexts (pp. 53-66). Routledge.

Giambrone, A. (2016). Dramatic encounters: Drama pedagogy and conflict social justice teaching [Doctoral dissertation, University of Toronto]. TSpace. http://hdl.handle.net/1807/72998

Giroux, H. A. (1993). Introduction. In P. McLaren (Ed.), Schooling as a ritual performance: Towards a political economy of educational symbols and gestures (2nd ed., p. xxiv). Routledge.

Giroux, H. A. (2011). On critical pedagogy. Continuum.

Gjaerum, R. G. (2013). Applied theatre research: Discourses in the field. European Scientific Journal, Special Edition(3), 347-361. https://doi.org/10.19044/esj.2013.v9n10p\%25p

Greene, M. (1991). Texts and margins. Harvard Educational Review, 61(1), 27-39.

Hackman, H. W. (2005). Five essential components for social justice education. Equity and Excellence in Education, 38, 103-109. https://doi.org/10.1080/10665680590935034

Jackson, T. (2001). Learning through theatre. Routledge.

Kumashiro, K. (2000). Towards a theory of anti-oppressive education. Review of Educational Research, 70(1), 25-53. https://doi.org/10.3102\%2F00346543070001025

Kumashiro, K. (2009). Against common sense: Teaching and learning toward social justice. Routledge.

Lu, Yi-Hsin. (2002). Theatre in education: Catalyst for change. [Unpublished master's dissertation]. University of Montana. 
McDonald, M., \& K. M. Zeichner. (2009). Social justice teacher education. In W. Ayers, T. Quinn, \& D. Stovall (Eds.), Handbook of social justice in education (pp. 595-610). Routledge.

McLaren, P. (1989). Life in schools: An introduction to critical pedagogy in the foundations of education. Longman.

Neelands, J. (2007). Taming the political: The struggle over recognition in the politics of applied theatre. Research in Drama Education, 12(3), 305-317. https://doi.org/10.1080/13569780701560388

Österlind, E. (2008). Acting out of habits: Can Theatre of the Oppressed promote change? Boal's theatre methods in relation to Bourdieu's concept of habitus. Research in Drama Education, 13(10), 71-82.

https://www.tandfonline.com/doi/figure/10.1080/13569780701825328?scroll=top\&needAccess =true

Pineau, E. L. (1994). Teaching is performance: Reconceptualizing a problematic metaphor. American Educational Research Journal, 31, 3-25. https://doi.org/10.3102\%2F00028312031001003

Siegesmund, R. (1998). Why do we teach art today? Conceptions of art education and their justification. Studies in Art Education, 39(3), 197-214. https://doi.org/10.2307/1320364

Tarlington, C., \& Michaels, W. (1995). Building plays: Simple playbuilding techniques at work. Pembroke.

Teoh, J. (2012). Drama as a form of critical pedagogy: Empowerment of justice. The Pedagogy of Theatre of the Oppressed International Journal, 1(1), 6-27.

https://www.academia.edu/1787353/Drama as a Form of Critical Pedagogy Empowerment of Justice

Valverde, C. P. (2003). Theatre-in-education in the context of educational drama. Semantic Scholar. https://www.semanticscholar.org/paper/Theatre-in-education-(TIE)-in-the-context-of-dramaValverde/fa93fe115977c906b496960ff83850ac9a409d7d

Werner, R. (2017). Drama for social justice: Embodying identity and emotion in ELT [Master's thesis, SIT Graduate Institute]. MA TESOL Collection.

https://digitalcollections.sit.edu/cgi/viewcontent.cgi?referer=\&httpsredir=1\&article=1724\&conte xt=ipp collection 